\title{
Sunflower fertigated with potassium fertilization in two agricultural seasons in the Brazilian semiarid region ${ }^{1}$
}

\author{
Girassol fertirrigado com adubação potássica em duas safras agrícolas no semiárido \\ Brasileiro
}

\author{
Allysson Pereira dos Santos ${ }^{2}$, Francilene de Lima Tartaglia ${ }^{3}$, Almir Rogerio Evangelista de Souza ${ }^{3}$, Manoel \\ Galdino dos Santos ${ }^{2}$, Lindomar Maria da Silveira² and Aurélio Paes Barros Júnior ${ }^{2 *}$
}

\begin{abstract}
The objective of this study was to evaluate the effect of potassium doses on the production components of sunflower cultivars grown in the semiarid climate region. The experiment was carried out in two agricultural seasons, in 2016 and 2017, at the Rafael Fernandes Experimental Farm, Mossoró, RN, Brazil. The experimental design used was randomized blocks, in split plots, with four replicates. Five potassium doses were evaluated in the plots: 0, 30, 60, 90 and $120 \mathrm{~kg} \mathrm{ha}^{-1}$ of $\mathrm{K}_{2} \mathrm{O}$, and four sunflower cultivars were evaluated in the subplots: Aguará 6, Altis 99, Multissol and BRS 122. The evaluated characteristics were: $\mathrm{K}$ content in the diagnostic leaf (KDL), thousand-achene weight (TAW), achene yield (AY), oil content (OC) and oil yield (OY). Potassium doses directly influenced agronomic variables, promoting better performance. The best $\mathrm{K}_{2} \mathrm{O}$ doses for sunflower yield were 77.7 and $80.2 \mathrm{~kg} \mathrm{ha}^{-1}$ in the first season for the cultivars Altis 99 and Aguará 6, and 65.9 and $69.5 \mathrm{~kg} \mathrm{ha}^{-1}$ in the second season for Altis 99 and Aguará 6. In the first season, the production results were higher than in the second, and the cultivars Aguará 6 and Altis 99 obtained the highest achene yield and oil yield in both agricultural seasons.
\end{abstract}

Key words: Helianthus annuus L.. Potassium doses. Plant nutrition. Yield. Oilseed crop.

RESUMO - O objetivo do estudo foi avaliar o efeito de doses de potássio sobre os componentes de produção de cultivares de girassol cultivado na região de clima semiárido. O experimento foi realizado em duas safras agrícolas, nos anos de 2016 e 2017, na Fazenda Experimental Rafael Fernandes, Mossoró, RN. O delineamento experimental utilizado foi em blocos ao acaso, em parcelas subdivididas, com quatro repetições. Nas parcelas, foram avaliadas cinco doses de potássio: 0, 30, 60, 90 e $120 \mathrm{~kg} \mathrm{ha}^{-1} \mathrm{de} \mathrm{K}_{2} \mathrm{O}$, e nas subparcelas, quatro cultivares de girassol: Aguará 6, Altis 99, Multissol e BRS 122. As características de avaliadas foram: teor de K na folha diagnóstica (TKF), massa de mil aquênios (MMA), produtividade de aquênios (PA), teor de óleo (TO) e produtividade de óleo (PO). As doses de potássio influenciaram diretamente nas variáveis agronômicas, proporcionado melhor desempenho. As melhores doses foram 77,7 e 80,2 $\mathrm{kg} \mathrm{ha}^{-1} \mathrm{de}_{2} \mathrm{O}$ na primeira safra para as cultivares Altis 99 e Aguará 6, e na segunda safra, 65,9 e 69,5 kg ha ${ }^{-1}$ de $\mathrm{K}_{2} \mathrm{O}$ nas Altis 99 e Aguará 6, ambos para produtividade do girassol. Na primeira safra, os resultados produtivos foram superiores a segunda, e as cultivares Aguará 6 e Altis 99 obtiveram as maiores produtividades de aquênios e de óleo nas duas safras agrícolas.

Palavras-chave: Helianthus annuus L.. Doses de potássio. Nutrição de plantas. Produtividade. Oleaginosa.

\footnotetext{
DOI: $10.5935 / 1806-6690.20200023$

*Author for correspondence

Received for publication in 03/04/2019; approved in 05/11/2019

${ }^{1}$ Parte da Tese do primeiro autor apresentada ao Curso de Pós-Graduação em Fitotecnia, Universidade Federal Rural do Semi-Árido/UFERSA

${ }^{2}$ Programa de Pós-Graduação em Fitotecnia, Departamento de Ciências Agronômicas e Florestais, Centro de Ciências Agrárias, Universidade Federal Rural do Semi-Árido/UFERSA, Mossoró-RN, Brasil, allyssoneng@gmail.com (ORCID ID 0000-0002-2224-241X), manoel.galdino5@gmail.com (ORCID ID 0000-0003-4972-5849), lindomarmaria@ufersa.edu.br (ORCID ID 0000-0001-9719-7417), aurelio.barros@ufersa.edu.br (ORCID ID 0000-0002-6983-8245)

${ }^{3}$ Instituto Federal de Educação, Ciência e Tecnologia de Alagoas, Campus Piranhas, Piranhas-AL, Brasil, francilene.tartaglia@ifal.edu.br (ORCID ID 0000-0001-6023-0033), almir.souza@ifal.edu.br (ORCID ID 0000-0002-9266-5063)
} 


\section{INTRODUCTION}

Sunflower (Helianthus annuus L.) has become an oilseed species of great importance in the world economy, due to its high yields of achenes and oil with high quality, so it has stood out as an alternative source in the production of biofuels (CASTRO et al., 2010; CASTRO; LEITE, 2018; DALCHIAVON; MALACARNE; CARVALHO, 2016).

Sunflower production requires greater availability in the supply of water and nutrients throughout the cycle. When cultivated in hot and dry climate environments with situations of nutritional scarcity, it requires greater supply of chemical fertilizers, to prevent nutritional restrictions from causing large variations in its production results (GARCÍA-LÓPEZ et al., 2014). Potassium is one of the important nutrients for sunflower, and its application in the form fertilizer can influence both morphological characteristics and yield (SOARES et al., 2015).

The potassium cycle in soil and plant becomes a factor of great relevance for production, because it is a nutrient that is required in large amounts and its export rate occurs at low intensity (CASTRO et al., 2014).

Although potassium is the most extracted nutrient by this species, potassium fertilization has been little studied so far, compared to nitrogen fertilization (ZOBIOLE et al., 2010). Thus, some researchers state that sunflower can also promote improvement in soil physical properties, caused by indirect effects through its roots (CASTRO et al., 2010).

Sunflower cultivation becomes economically viable with high yield in response to the set of factors, such as fertilization, that meet its requirements. In the northeastern semiarid region, studies with irrigated sunflower cultivation recommend nitrogen and phosphorus doses for higher production performance (BRAGA, 2018; SOARES et al., 2016). However, studies with potassium fertilization are still scarce in the Brazilian semiarid region.

Thus, the objective of this study was to evaluate the effect of potassium doses on the production components of sunflower cultivars grown in the Brazilian semiarid region.

\section{MATERIAL AND METHODS}

The experiments were conducted at the Rafael

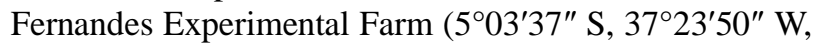
$72 \mathrm{~m}$ altitude), belonging to the Federal Rural University of the Semi-Arid Region (UFERSA), from March to June 2016 (first agricultural season) and from March to June 2017 (second agricultural season), in different areas of cultivation. The soil of the experimental area was classified as Latossolo Vermelho Amarelo Distrófico (Oxisol), according to the Brazilian Soil Classification System (EMPRESA BRASILEIRA DE PESQUISA AGROPECUÁRIA, 2013).

According to Thornthwaite, the local climate is DdAa, i.e. semiarid, megathermal and with few precipitations during most of the year, and according to Köppen's classification, the climate is BSwh', described as dry and hot, with an average temperature of $27.4{ }^{\circ} \mathrm{C}$ and average precipitations of $673.9 \mathrm{~mm}$ (CARMO FILHO; OLIVEIRA, 1995). The average meteorological data along the experimental periods are illustrated in Figure 1.

The experimental design was randomized blocks, using split plots, with four replicates. Potassium doses ( 0 , $30,60,90$ and $120 \mathrm{~kg} \mathrm{ha}^{-1}$ of $\mathrm{K}_{2} \mathrm{O}$ ) were distributed in the plots, and sunflower cultivars (Aguará 6, Multissol, Altis 99 and BRS 122) were distributed in the subplots.

Figure 1 - Average daily values of rainfall, mean air temperature and relative humidity, corresponding to the months from March to June of the agricultural seasons of 2016 and 2017

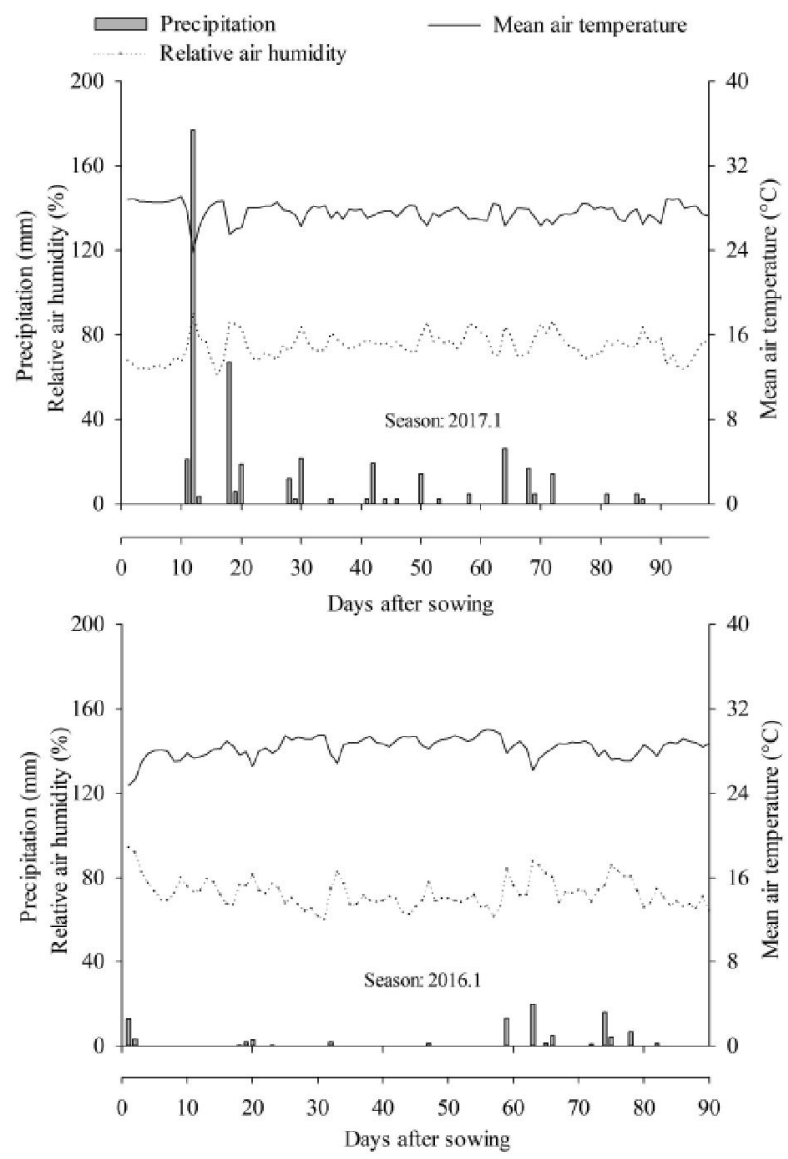


The experimental subplots consisted of four rows with length of 4.5 meters each, spaced by $0.7 \mathrm{~m}$, with an area of $12.6 \mathrm{~m}^{2}(2.8 \times 4.5 \mathrm{~m})$. The usable area of the plot with $5.46 \mathrm{~m}^{2}$ was composed of two central rows, disregarding one plant on each end. The spacing used was $0.7 \mathrm{~m}$ between rows and $0.3 \mathrm{~m}$ between plants, totaling approximately 47,600 plants per hectare.

Soil samples were collected before installing the experiments for chemical analysis in both experimental areas. It was found that soil $\mathrm{pH}$ values were 3.54 and 3.25 in each area. After the results of the analysis, liming was performed in the experimental areas using dolomitic limestone according to the recommendation of Ribeiro, Guimarães and Alvarez (1999). Then, new soil samplings were performed in both experimental areas at 40 days after application (Table 1).

After 45 days of liming in the experimental areas during the two agricultural seasons, basal fertilizations recommended for sunflower crop were carried out, followed by planting (RIBEIRO; GUIMARÃES; ALVAREZ, 1999).

In the two agricultural seasons, fertilizers were applied via fertigation, and the fertilizer recommendations used for sunflower crop followed the fertilizer recommendation of Ribeiro, Guimarães and Alvarez (1999), except for potassium, which was applied according to the treatments used, at doses of $0,30,60,90$ and $120 \mathrm{~kg}$ of $\mathrm{K}_{2} \mathrm{O}$.

In nitrogen fertilization (urea) with $70 \mathrm{~kg} \mathrm{ha}^{-1}, 20 \%$ of the dose was applied at planting and the remainder was split into two top-dressing fertilizations, applying $40 \%$ of the $\mathrm{N}$ dose at 30 days after emergence (DAE) and the other $40 \%$ at 50 DAE. In phosphate fertilization, $70 \mathrm{~kg} \mathrm{ha}^{-1}$ of MAP were applied only as basal. For boron, $1 \mathrm{~kg} \mathrm{ha}^{-1}$ of boric acid was applied at 30 days after planting (DAP).

In potassium fertilization, potassium chloride $(\mathrm{KCl})$ was used as a source, split into two applications, the first part containing $50 \%$ of the dose applied at planting, and the remaining $50 \%$ at 30 DAE. Chemical fertilizers were applied in the irrigation water, after dilution in water, using a by-pass pipe (locally known as "pulmão", i.e. lung). Boron fertilization was performed through the leaves, with the aid of a backpack sprayer. Irrigation was daily applied using a localized drip system, with spacing of $0.70 \mathrm{~m}$ between tapes and $0.30 \mathrm{~m}$ between emitters, with average flow rate of $1.5 \mathrm{~L} \mathrm{~h}^{-1}$, considering the precipitation and evapotranspiration of the crop $(\mathrm{mm})$ at its phenological stages (ALLEN, 1998; CAVALCANTE JUNIOR et al., 2013).

Planting was carried out on March 9, 2016, in the first agricultural season and on March 9, 2017, in the second season. Sowing was performed manually, and thinning was carried out ten days after planting. Sunflower harvests occurred after the plants reached the phenological stage R9. In the 2016 season, the cultivars Multissol and BRS 122 were harvested at 84 days after sowing (DAS) and the cultivars Aguará 6 and Altis 99 at 90 DAS. In the 2017 season, Multissol and Embrapa 122 were harvested at 90 DAS and Aguará 6 and Altis 99 at 98 DAS.

The first characteristic evaluated was the $\mathrm{K}$ content in the diagnostic leaf (KDL), with collection of the sixth leaf per plant during the R5 stage, beginning of flowering, using 28 leaves from the usable area in all plots of the experiments (CORTEZ et al., 2014). After drying in an oven, the samples were ground and subjected to sulfuric digestion (MALAVOLTA; VITTI; OLIVEIRA, 1997). The readings to quantify $\mathrm{K}$ content were performed in a flame photometer.

The second characteristic evaluated was thousand-achene weight (TAW) (g). The third characteristic was achene yield (AY) $(\mathrm{kg} \mathrm{ha-1})$, determined by weight of achenes in plants of the usable plot of each treatment, with the correction of moisture to $11 \%$ (GRILO JÚNIOR; AZEVEDO, 2013). The fourth characteristic was the percentage of oil content (OC), determined by extraction using hexane solvent in Sohxlet extractor (YANIV et al., 1998). The fifth and last characteristic was oil yield $(\mathrm{OY})\left(\mathrm{kg} \mathrm{ha}^{-1}\right)$, determined using the formula $(\mathrm{OY}=\mathrm{AY} \times \mathrm{OC} / 100)$, where: $(\mathrm{OY}=$ oil yield; $\mathrm{AY}=$ achene yield and $\mathrm{OC}=$ oil content).

The analyses of variance of the agricultural seasons were performed individually for all characteristics evaluated, and then a joint analysis was applied. Regression analyses were used for quantitative data and Tukey test $(\mathrm{p}<0.05)$ was used for qualitative data.

Table 1 - Physical-chemical characterization of the soil in the experimental area where the experiments were installed

\begin{tabular}{|c|c|c|c|c|c|c|c|c|c|c|c|}
\hline \multirow{2}{*}{ Season } & Sand & Silt & Clay & $\mathrm{pH}$ & $\mathrm{OM}$ & $\mathrm{P}$ & $\mathrm{K}^{+}$ & $\mathrm{Ca}^{+2}$ & $\mathrm{Mg}^{+2}$ & $\mathrm{Al}^{3+}$ & $\mathrm{H}+\mathrm{Al}$ \\
\hline & \multicolumn{3}{|c|}{$\mathrm{kg} \mathrm{kg}^{-1}$} & water & $\mathrm{g} \mathrm{kg}^{-1}$ & \multicolumn{2}{|c|}{$\mathrm{mg} \mathrm{dm}^{-3}$} & \multicolumn{4}{|c|}{$\mathrm{cmol} \mathrm{dm}^{-3}$} \\
\hline 2016 & 0.90 & 0.02 & 0.08 & 5.90 & 7.52 & 2.21 & 27.1 & 0.40 & 0.57 & 0.00 & 1.49 \\
\hline 2017 & 0.88 & 0.02 & 0.10 & 5.80 & 4.38 & 1.9 & 32.4 & 1.40 & 0.70 & 0.00 & 1.98 \\
\hline
\end{tabular}




\section{RESULTS AND DISCUSSION}

For the studied variables, there was homogeneity of variances between agricultural seasons and, consequently, a joint analysis was applied. There was a triple significant interaction between potassium doses, sunflower cultivars and agricultural seasons for the variable achene yield (AY) and for oil content (OC). For oil yield (OY), there were double interactions: doses $\mathrm{x}$ cultivars, doses $\mathrm{x}$ seasons and seasons $\mathrm{x}$ cultivars. Regarding the $\mathrm{K}$ content in the diagnostic leaf (KDL), there were interaction of doses $x$ cultivars and single effect of seasons. Thousand-achene weight (TAW) was significantly affected only by the single factors.

Leaf analysis showed a significant effect of doses $\mathrm{X}$ cultivar, with lowest $\mathrm{K}$ content at the $\mathrm{K}_{2} \mathrm{O}$ dose of $0 \mathrm{~kg} \mathrm{ha}^{-1}$ and, from the $\mathrm{K}_{2} \mathrm{O}$ doses of 30 to $120 \mathrm{~kg} \mathrm{ha}^{-1}$, there were increasing effects on the accumulation of this nutrient in the evaluated leaf. The cultivars showed similar K contents as a function of the doses, but there was variation in values from $37.3 \mathrm{~g} \mathrm{~kg}^{-1}$, corresponding to the $\mathrm{K}_{2} \mathrm{O}$ dose of $0 \mathrm{~kg} \mathrm{ha}^{-1}$ up to the maximum content of $67.2 \mathrm{~g} \mathrm{~kg}^{-1}$, at the $\mathrm{K}_{2} \mathrm{O}$ dose of $120 \mathrm{~kg} \mathrm{ha}^{-1}$ (Figure 2). Regarding the single effect of agricultural seasons, it was found that in the second season the mean $\mathrm{K}$ content in the diagnostic leaf was higher than that of the first season, as also occurred for thousandachene weight (Table 2).

Astudy on the nutritional, agronomic and production aspects of irrigated sunflower cultivars in Minas Gerais found that the overall mean for $\mathrm{K}$ content in the leaf collected at the full flowering stage was $35.91 \mathrm{mg} \mathrm{kg}^{-1}$ in $\mathrm{K}_{2} \mathrm{O}$ (AQUINO; SILVA; BERGER, 2013), which is lower than that found in the present study.

According to the variation in $\mathrm{K}$ content in the diagnostic leaf between cultivars as a function of the doses used, it was also confirmed the influence

Table 2 - Mean values of potassium content in the diagnostic leaf (KDL) and thousand-achene weight (TAW) of sunflower cultivars as a function of agricultural seasons in the Brazilian semiarid region

\begin{tabular}{ccc}
\hline Agricultural seasons & KDL $\left(\mathrm{mg} \mathrm{kg}^{-1}\right)$ & TAW $(\mathrm{g})$ \\
\hline 2016 & $52.05 \mathrm{~b}$ & $43.13 \mathrm{~b}$ \\
2017 & $53.28 \mathrm{a}$ & $44.71 \mathrm{a}$ \\
$\mathrm{CV} 1(\%)$ & 4.09 & 5.34 \\
CV2(2) & 7.41 & 7.59 \\
Overall mean & 52.62 & 42.42 \\
\hline
\end{tabular}

* Means followed by the same lowercase letters in the columns do not differ statistically by Tukey test at $5 \%$ probability level
Figure 2 - Potassium content in the diagnostic leaf of sunflower cultivars as a function of potassium doses in the Brazilian semiarid region

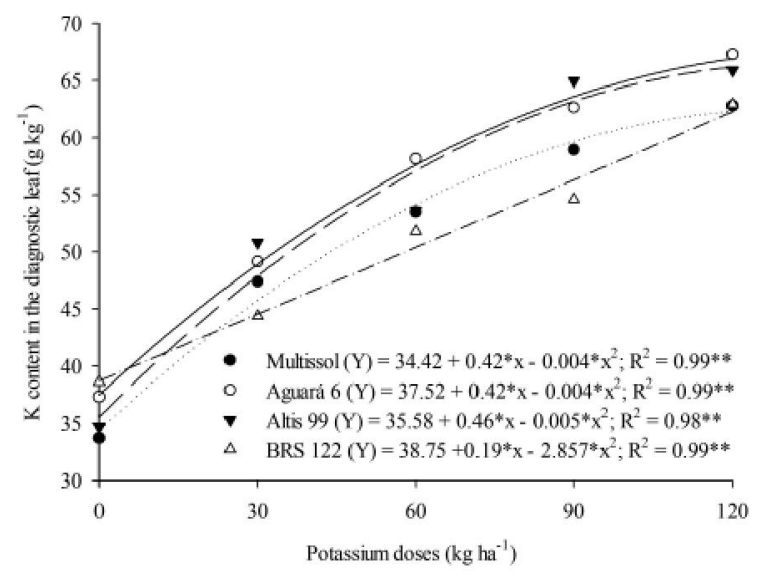

of environmental factors on these results, due to the climatic variations along the two growing seasons. In the first season (2016), the highest average rainfall recorded in the period was $73.0 \mathrm{~mm}$, whereas the second season (2017) had rains above the normal for the region, and the highest average recorded between March and June was $188.4 \mathrm{~mm}$. During the two agricultural seasons in these periods of each year, the global solar radiation showed very close ranges in the mean values of $21.4 \mathrm{MJ} \mathrm{m}^{-2}$ day $^{-1}$ in 2016 and $20.3 \mathrm{MJ} \mathrm{m}^{-2}$ day $^{-1}$ in 2017 (Figure 1).

These data confirmed the direct influence of climatic conditions on the second season in comparison to the first one. The greater water supply during the same period from one season to another favored the reaction of the limestone used in liming, making available a greater amount of nutrients such as calcium and magnesium, as well as a greater interaction with potassium in the soil solution for plants (Table 1).

Another important factor for sunflower is the incidence of global solar radiation required by the crop, which was sufficient during the achene filling stage. Thus, it favored the increase in the results produced, leading to variation in the means between cultivars and doses, in the agricultural seasons.

For the thousand-achene weight, there was significant single effect of cultivars according to the different means presented (Table 3). The cultivar Aguará 6 obtained the highest average, $44.77 \mathrm{~g}$, while Multissol had the lowest value, $38.71 \mathrm{~g}$. Potassium doses also caused single effects (Figure 3 ). Thousand-achene weight is described in the literature with a range of variation of 30 - $60 \mathrm{~g}$ between sunflower cultivars (FRANK; SZABO, 1989). The values found in the present study were lower 
Table 3 - Thousand-achene weight (TAW) of sunflower cultivars as a function of potassium doses in the Brazilian semiarid region

\begin{tabular}{cc}
\hline Cultivars & TAW $(\mathrm{g})$ \\
\hline Multissol & $38.71 \mathrm{c}$ \\
Altis 99 & $43.96 \mathrm{ab}$ \\
Aguará 6 & $44.77 \mathrm{a}$ \\
BRS 122 & $42.25 \mathrm{~b}$ \\
\hline CV1 (\%) & 5.34 \\
CV2 (\%) & 7.59 \\
Overall mean & 42.42 \\
\hline
\end{tabular}

*Means followed by the same letter in the column do not differ statistically by Tukey test at $5 \%$ probability level

Figure 3 - Thousand-achene weight (TAW) of sunflower cultivars as a function of potassium doses in the Brazilian semiarid region

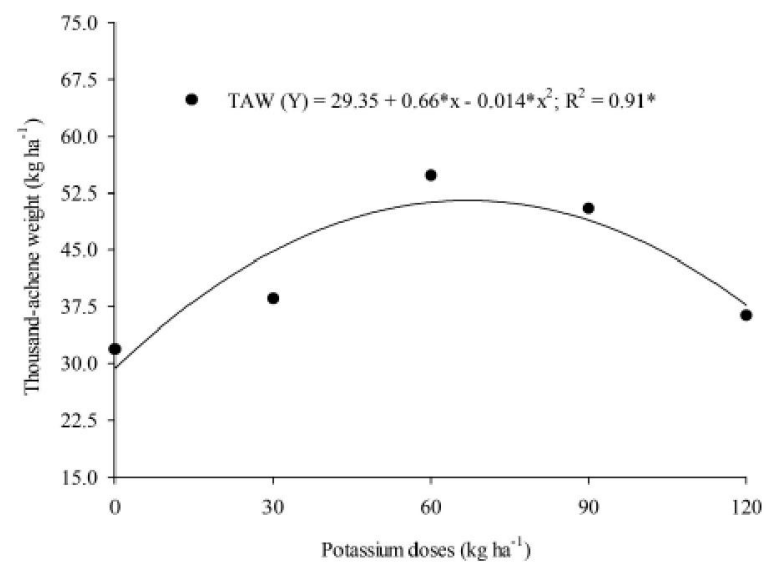

than those described for the cultivars BRS 122, Aguará 6 and Multissol, which are 60, 46 and $76.27 \mathrm{~g}$, respectively (DALCHIAVON; MALACARNE; CARVALHO, 2016; EMPRESA BRASILEIRA DE PESQUISA AGROPECUÁRIA, 2008; MARCHESINI et al., 2018).

An increase was observed in the thousand-achene weight compared to the control up to the $\mathrm{K}_{2} \mathrm{O}$ dose of $60 \mathrm{~kg} \mathrm{ha}^{-1}$, with reduction in the results as the doses increased. From the dose zero to the maximum value reached with the application of $60 \mathrm{~kg} \mathrm{ha}^{-1}$ of $\mathrm{K}_{2} \mathrm{O}$, there was a progressive increase in the values, which were equal to 31.9 and $54 \mathrm{~g}$ at the doses 0 and $60 \mathrm{~kg} \mathrm{ha}^{-1}$. For $\mathrm{K}_{2} \mathrm{O}$ doses of 90 and $120 \mathrm{~kg}$, there was a reduction in the results, and the obtained values were $50.5 \mathrm{~g}$ and $36.3 \mathrm{~g}$, respectively.

The reduction in thousand-achene weight is probably related to the phytotoxic effects with the use of the highest doses of $\mathrm{K}$, due to the excess of this nutrient, which soon after reaching the optimal level for TAW caused effects, from its luxury supply to toxicity. Plants require adjusted doses, because the use of excessive doses of chemical fertilizers such as those described in this study, besides causing inefficiency in the use of nutrients, may also generate negative environmental impacts (REETZ JUNIOR, 2017).

The use of the highest doses of $\mathrm{K}_{2} \mathrm{O}$ caused reduction in thousand-achene weight (Figure 3). According to Viana et al. (2008), results pointing to reduction in thousand-achene weight are related to some nutritional insufficiency that occurred in the plant.

The use of higher $\mathrm{K}$ doses caused reduction in thousand-achene weight, demonstrating that this nutrient in large quantities causes a negative effect on sunflower production performance. A study confirmed that the high concentrations of $\mathrm{K}$ fertilizers generate antagonistic effects between nutrients, so their action inhibits the absorption of other cations such as calcium and magnesium, and nutritional deficits in the plant will have effects, reducing its yield (FORTALEZA et al., 2005).

$\mathrm{K}$ doses caused similar effects of increase and subsequent decrease in achene yield (Figures $4 \mathrm{~A}$ and $4 \mathrm{~B}$ ) and oil content (Figures 4C and 4D). After reaching the maximum point of absorption of this nutrient, sunflower cultivars were not able to assimilate it properly and the excess of this fertilizer affected the results, causing decreasing responses in both agricultural seasons.

In regard to the $\mathrm{K}$ doses and cultivars, there was significant effect of the first season, and the maximum technical efficiencies were obtained at $\mathrm{K}_{2} \mathrm{O}$ doses of 77.7 and $80.2 \mathrm{~kg} \mathrm{ha}^{-1}$ (Altis 99 and Aguará 6), which promoted the highest achene yields, equal to $1,735.58 \mathrm{~kg} \mathrm{ha}^{-1}$ and $2,120.39 \mathrm{~kg} \mathrm{ha}^{-1}$, respectively. For the cultivars Multissol and BRS 122, the maximum efficiencies were obtained at the $\mathrm{K}_{2} \mathrm{O}$ doses of 73.7 and $79.9 \mathrm{~kg} \mathrm{ha}^{-1}$, with highest achene yields of $1,010.01 \mathrm{~kg} \mathrm{ha}^{-1}$ and $1,080.76 \mathrm{~kg} \mathrm{ha}^{-1}$, respectively. In the second season, the highest averages for achene yield, at $\mathrm{K}_{2} \mathrm{O}$ doses of 65.9 and $69.5 \mathrm{~kg} \mathrm{ha}^{-1}$, were obtained again by the cultivars Aguará 6, producing $1,723.98 \mathrm{~kg} \mathrm{ha}^{-1}$, and Altis 99, with $1571.89 \mathrm{~kg} \mathrm{ha}^{-1}$, followed by the cultivars Multissol and BRS 122, which produced $1,387.27 \mathrm{~kg} \mathrm{ha}^{-1}$ and $1,411.28 \mathrm{~kg} \mathrm{ha}^{-1}$ at $\mathrm{K}_{2} \mathrm{O}$ doses of 70.4 and $69.1 \mathrm{~kg} \mathrm{ha}^{-1}$, respectively.

The result of achene yield obtained by the cultivar Aguará 6 was the best in both agricultural seasons, with high production responses. A study conducted in the state of Mato Grosso, with the cultivar Altis 99, found that the highest average achene yield was $1,835.8 \mathrm{~kg} \mathrm{ha}^{-}$ ${ }^{1}$ (DALCHIAVON et al., 2016). Another study, using K doses in sunflower in the state of Roraima, found that 
Figure 4 - Achene yield (A, B) and oil content (C, D) of sunflower cultivars as a function of potassium doses in the Brazilian semiarid region
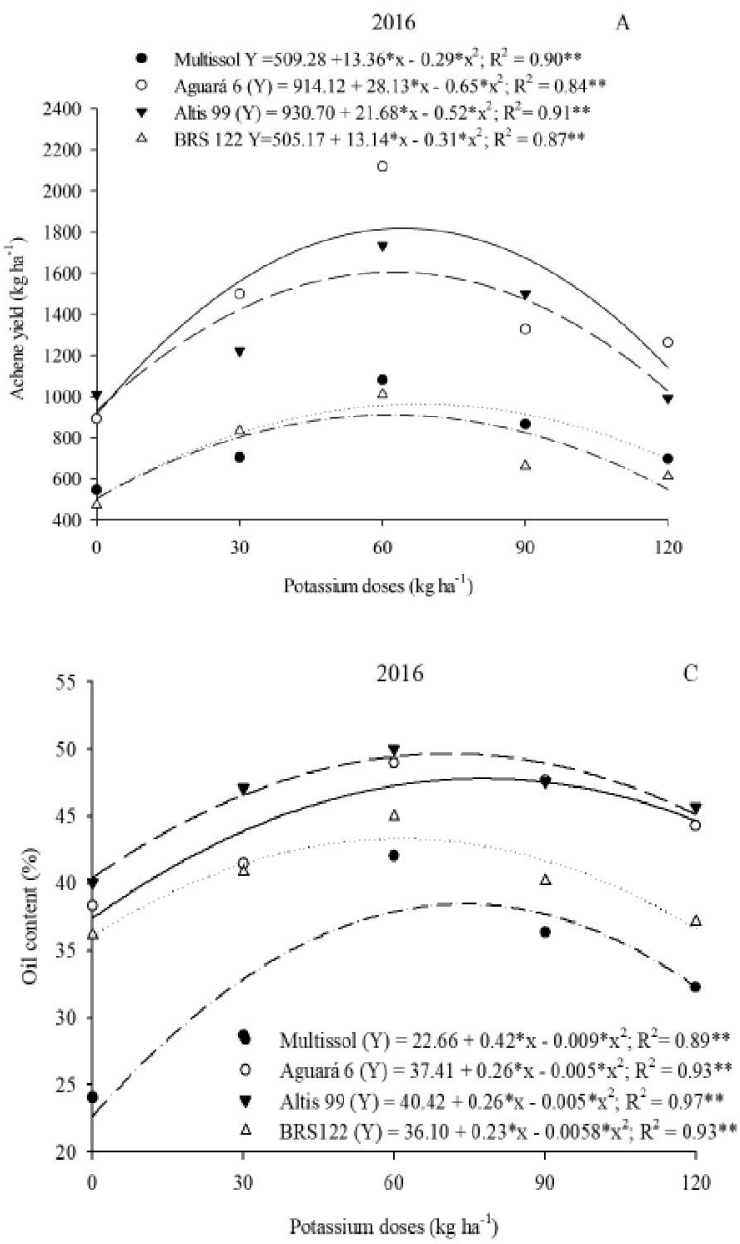

the maximum achene yield was $2,083.3 \mathrm{~kg} \mathrm{ha}^{-1}$, obtained with the $\mathrm{K}_{2} \mathrm{O}$ dose of $83.8 \mathrm{~kg} \mathrm{ha}^{-1}$ (UCHÔA et al., 2011). These values are similar and corroborate the results found in the study conducted under the conditions of the Brazilian semiarid region.

In the second season, the cultivar BRS 122 obtained the best achene yield, $1,411.28 \mathrm{~kg} \mathrm{ha}^{-1}$, with the dose of $69.1 \mathrm{~kg} \mathrm{ha}^{-1}$. The result found in the present study is higher than the highest yield obtained by Poletine et al. (2013), who conducted a study in the northwest region of Paraná and observed maximum yield of 612.5 $\mathrm{kg} \mathrm{ha}^{-1}$ for the cultivar BRS 122. A study conducted in the state of Ceará, evaluating the vegetative behavior and production of sunflower, reported highest achene yield of $1,516.57 \mathrm{~kg} \mathrm{ha}^{-1}$ (BEZERRA et al., 2014), similar to that found in the present study.

Regarding the oil content for the first season, the cultivars Altis 99 and Aguará 6 showed the highest
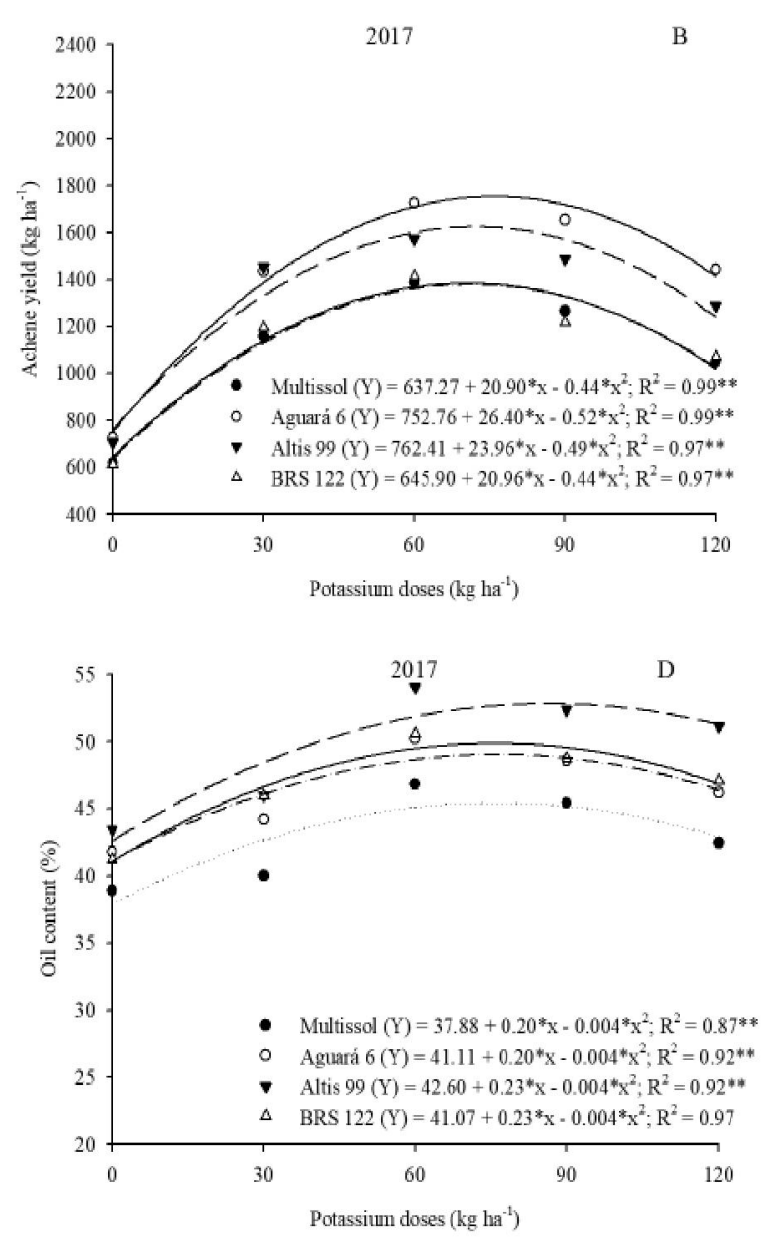

percentages, with values of $50.07 \%$ and $49.00 \%$, respectively, which are the highest averages. Conversely, the cultivars BRS 122 and Multissol had the lowest averages, equal to $45.00 \%$ and $42.07 \%$, respectively. During the second season, the highest percentages of oil were obtained by the cultivars Altis 99, BRS 122 and Aguará 6, with values of $54.07 \%, 50.61 \%$ and $50.23 \%$, respectively, while Multissol obtained the lowest average, $46.86 \%$. In view of these results, it was observed that the $\mathrm{K}$ doses that led to the highest achene yields were the ones that generated the best result for oil content.

The variations in the results of both achene yield and oil content may be related to the local climatic conditions, which probably influenced the genetic characteristics of the cultivars (Figure 1). In this case, these factors were decisive for the occurrence of varied response between the cultivars in both agricultural 
seasons. Besides the rainfall during this period, the temperatures also influenced, and the maximum average temperatures were $29.1{ }^{\circ} \mathrm{C}$ in 2016 and $27.4^{\circ} \mathrm{C}$ in 2017. In Dourados, Mato Grosso do Sul, a study with different cultivation season of sunflower found that the increase in oil content was influenced by the cultivation season (SOUZA et al., 2015).

The rains occurred in this period were decisive for the results found, as they influenced the increase of $\mathrm{K}$ content in the diagnostic leaf. It also positively affected the oil content, which was higher in second season than in the first one. The higher concentration of rains in 2017 provided favorable conditions for the cultivars to obtain greater accumulation of oil in achenes, compared to the results of 2016 (Figure 1). These results were greatly satisfactory, considering that the national average is $1,669 \mathrm{~kg} \mathrm{ha}^{-1}$ (COMPANHIA NACIONAL DE ABASTECIMENTO, 2019).

Potassium doses had influence along the production process, directly interfering in all agronomic responses among the sunflower cultivars. This interfered with oil yield as there were double interactions of doses $x$ cultivars (Figure 5A), doses $x$ agricultural seasons (Figure 5B) and seasons $x$ cultivars (Table 4).

In the variable oil yield, there was a significant difference in the results of the cultivars between the agricultural seasons, due to the effect of $\mathrm{K}$ doses, associated with the climatic conditions along the cultivation period, which favored this variation through the different responses obtained. The highest values were obtained by the cultivars Aguará 6 and Altis 99, with averages of $1,040.04$ and $893.82 \mathrm{~kg} \mathrm{ha}^{-1}$ of oil, respectively, recorded in the first season at $\mathrm{K}_{2} \mathrm{O}$ doses of 77.7 and $80.2 \mathrm{~kg} \mathrm{ha}^{-1}$. For the cultivars Multissol and BRS 122, the maximum values were $631.75 \mathrm{~kg} \mathrm{ha}^{-1}$ and $679.77 \mathrm{~kg} \mathrm{ha}^{-1}$, obtained at the $\mathrm{K}_{2} \mathrm{O}$ doses of 73.7 and $79.9 \mathrm{~kg} \mathrm{ha}^{-1}$, respectively. In the second season, the $\mathrm{K}_{2} \mathrm{O}$ doses of 65.9 and $69.5 \mathrm{~kg} \mathrm{ha}^{-1}$ led to the highest oil yields, which were obtained by Aguará 6, producing $866.44 \mathrm{~kg}$ $\mathrm{ha}^{-1}$ and Altis 99 , with $849.23 \mathrm{~kg} \mathrm{ha}^{-1}$. The lowest yields were recorded for the cultivars BRS 122 and Multissol, with values of 714.06 and $648.41 \mathrm{~kg} \mathrm{ha}^{-1}$ of oil, at $\mathrm{K}_{2} \mathrm{O}$ doses 70.4 and $69.1 \mathrm{~kg} \mathrm{ha}^{-1}$, respectively.

A study on the oil yield of sunflower and its adaptation in several Brazilian regions found that the cultivars obtained different responses, with maximum values of $437.6 \mathrm{~kg} \mathrm{ha}^{-1}$ in Rio Grande do Sul and $1282.0 \mathrm{~kg} \mathrm{ha}^{-1}$ in the Federal District (GRUNVALD et al., 2009). The difference in the results obtained for oil yield in the two agricultural seasons between sunflower cultivars and $\mathrm{K}$ doses was influenced by the adaptation of these materials, associated with climatic conditions (Figure 1).

Sunflower planting carried out in this period of the year did not allow the occurrence of large variations or even losses in the results obtained, in relation to the oil content accumulated in the achenes. Studies prove that sunflower planting with later sowing period can cause reduction of oil content in the achenes, due to the influence of the lower amount of solar radiation resulting from the shorter length of daylight (DOSIO et al., 2000; IZQUIERDO et al., 2008).

Figure 5 - Oil yield (A) as a function of the single-effect analysis of the interaction doses x sunflower cultivars, and oil yield (B) as a function of the single-effect analysis of the interaction doses $x$ agricultural seasons in the Brazilian semiarid region
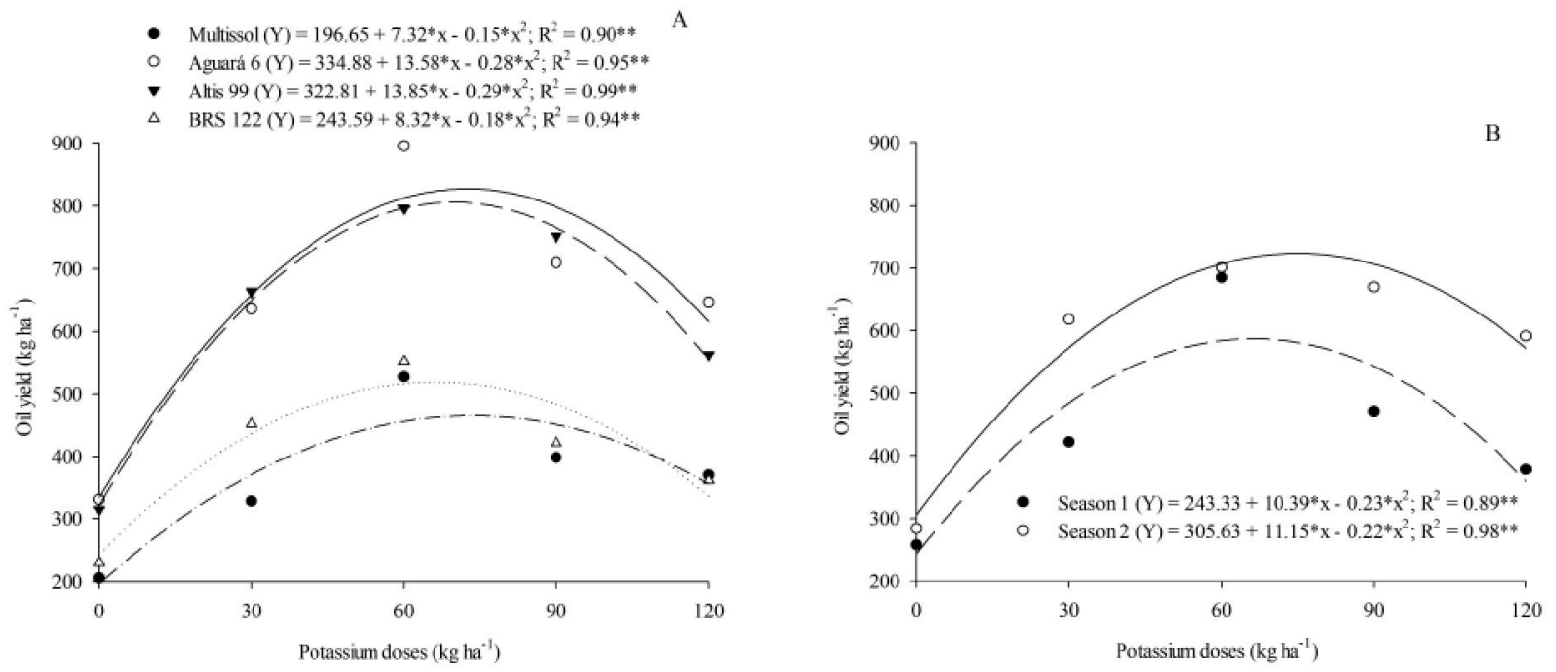
Table 4 - Mean values of oil yield (OY) of sunflower cultivars as a function of the single-effect analysis of the interaction cultivars $\mathrm{x}$ agricultural seasons

\begin{tabular}{ccccc}
\hline \multirow{2}{*}{ Seasons } & \multicolumn{4}{c}{ Cultivars } \\
\cline { 2 - 5 } & Multissol & BRS 122 & Aguará 6 & Altis 99 \\
\cline { 2 - 5 } & \multicolumn{4}{c}{ OY $\left(\mathrm{kg} \mathrm{ha}^{-1}\right)$} \\
\hline 2016 & $259.75 \mathrm{Cb}$ & $291.07 \mathrm{Cb}$ & $633.62 \mathrm{Aa}$ & $587.57 \mathrm{Ba}$ \\
\hline $\mathrm{CV} 1(\%)=14.04$ & $472.96 \mathrm{Ba}$ & $515.64 \mathrm{Ba}$ & $654.41 \mathrm{Aa}$ & $648.23 \mathrm{Aa}$ \\
\hline $\mathrm{CV} 2(\%)=14.89$ & & & \\
\hline Overall mean = 507.91 & & \\
*Means followed by the same letters, uppercase in the row and lowercase in the column, do not differ statistically by Tukey test at 5\% probability
\end{tabular}

The use of sunflower cultivars, as well as the use of different doses of $\mathrm{K}$, can provide important information on the production performance of sunflower in the northeastern semiarid region from the results obtained in this study. Thus, it corroborates other studies that indicate the existence of other factors interacting in this process, such as production components, which can directly influence sunflower yield (PIVETTA et al., 2012).

\section{CONCLUSIONS}

1. Potassium doses directly influence the evaluated characteristics of $\mathrm{K}$ content in the diagnostic leaf, thousand-achene weight, achene yield, oil content and oil yield, promoting better performance for sunflower cultivars in both agricultural seasons;

2. In the first season, the best $\mathrm{K}_{2} \mathrm{O}$ doses were 77.7 and $80.2 \mathrm{~kg} \mathrm{ha}^{-1}$ for the cultivars Altis 99 and Aguará 6, respectively, whereas in the second season, the best $\mathrm{K}_{2} \mathrm{O}$ doses were 65.9 and $69.5 \mathrm{~kg} \mathrm{ha}^{-1}$ for Altis 99 and Aguará 6 , in both cases for achene and oil yields;

3. The first season was superior to the second season, with the highest achene and oil yields.

\section{ACKNOWLEDGMENTS}

The present study was carried out with support from the Coordination for the Improvement of Higher Education Personnel - Brazil (CAPES) - Funding Code 001. Thanks to the National Council for Scientific and Technological Development (CNPq) and the Federal Rural University of the Semi-Arid Region (UFERSA), for supporting and allowing this research, conducted within the Graduate Program in Plant Science.

\section{REFERENCES}

ALLEN, R. G. et al. Crop evapotranspiration: guidelines for computing crop water requirements. Rome: FAO, 1998. p. 30-50.

AQUINO, L. A.; SILVA, F. D. B.; BERGER, P. G. Características agronômicas e o estado nutricional de cultivares de girassol irrigado. Revista Brasileira de Engenharia Agrícola e Ambiental, v.17, n.5, p.551-557, 2013.

BRAGA, D. F. Nitrogen and phosphorus fertilization of sunflower crop in alkaline Cambisol. Revista Brasileira de Engenharia Agrícola e Ambiental, v. 22, n. 2, p. 101-106, 2018.

BEZERRA, F. T. C. et al. Comportamento vegetativo e produtividade de girassol em função do arranjo espacial das plantas. Revista Ciência Agronômica, v. 45, n. 2, p. 335-343, 2014.

CARMO FILHO, F; OLIVEIRA, O. F. Mossoró: um município do semi-árido nordestino, caracterização climática e aspecto florístico. Mossoró: ESAM, 1995. 62 p. (Coleção Mossoroense, série B).

CASTRO, C. et al. Nutrição e fertilização de girassóis no cerrado brasileiro. In: Arribas, J. E. (ed.). Girassóis: crescimento e desenvolvimento, influências ambientais e pragas/doenças. Nova Iorque: Nova Science Pubs, 2014. p. 257-279.

CASTRO, C. et al. Sistema produtivo de girassol para a produção de biodiesel. In: CASTRO, A. M. G.; LIMA, S. M. V.; SILVA, J. F. V. (org.). Complexo agroindustrial de biodiesel no Brasil: competitividade das cadeias produtivas de matérias-primas. Brasília, DF: Embrapa Agroenergia, 2010. p. $376-420$.

CASTRO, C.; LEITE, R. M. V. B. C. Main aspects of sunflower production in Brazil. Oilseeds and fats, Crops and Lipids, v. 25, n. 1, p. 104-115, 2018.

CAVALCANTE JUNIOR, E. G. et al. Necessidade hídrica da cultura do girassol irrigado na chapada do Apodi. Revista Brasileira de Engenharia Agrícola e Ambiental, v. 17, n. 3, p. 261-267, 2013. 
COMPANHIA NACIONAL DE ABASTECIMENTO (BRASIL). Série histórica das safras: Girassol. 2019. Disponível em: https://www.conab.gov.br/info-agro/safras/ serie-historica-das-safras?start $=20$. Acesso em: 21 out. 2019.

CORTEZ, J. W. M. et al. Crecimiento, acumulación de macronutrientes y producción de melóncantaloupo y amarillo. Revista Caatinga, v. 27, n. 3, p. 72-82, 2014.

DALCHIAVON, F. C. et al. Características agronômicas e suas correlações em híbridos de girassol adaptados à segunda safra. Pesquisa Agropecuária Brasileira, v. 51, n. 11, p. 1806-1812, 2016.

DALCHIAVON, F. C.; MALACARNE, B. J.; CARVALHO, C. G. P. de. Características agronômicas de genótipos de girassol (Helianthus annuus L.) em segunda safra no Chapadão do Parecis - MT. Revista de Ciências Agrárias, v. 39, n. 1, p. 178186, 2016.

DOSIO, G. A. A. et al. Solar radiation intercepted during seed filling and oil production in two sunflower hybrids. Crop Science Society of América, v. 40, n. 6, p. 1637-1644, 2000.

EMPRESA BRASILEIRA DE PESQUISA AGROPECUÁRIA. Girassol: Embrapa 122/v-2000. Serviço de Negócios para Transferência de Tecnologia - Escritório de Negócios de Dourados-MS, 2008.

EMPRESA BRASILEIRA DE PESQUISA AGROPECUÁRIA. Sistema brasileiro de classificação de solos. Brasília, 2013. $353 \mathrm{p}$.

FORTALEZA, J. M. et al. Características físicas e químicas em nove genótipos de maracujá-azedo cultivado sob três níveis de adubação potássica. Revista Brasileira de Fruticultura, v. 27, n. 1, p. 124-127, 2005.

FRANK, J.; SZABO, L. A napraforgo Helianthus annuus, L. Budapest: Akadémiai Kiadó, 1989. 178 p.

GARCÍA-LÓPEZ, J. et al. Evaluation of three simulation approaches for assessing yield of rainfed sunflower in a Mediterranean environment for climate change impact modelling. Climatic Change, v. 124, n. 1, p. 147-162, 2014.

GRILO JÚNIOR, J. A. S.; AZEVEDO, P. V. Crescimento, desenvolvimento e produtividade do gergelim BRS Seda na agrovila de Canudos, em Ceará Mirim (RN). HOLOS, v. 2, p. 19-33, 2013.

GRUNVALD, G. A. K. et al. Adaptabilidade e estabilidade de genótipos de girassol nos estados do Rio Grande do Sul e Paraná. Ciência e Agrotecnologia, v. 33, n. 5, p. 1195-1204, 2009.
IZQUIERDO, N. G. et al. Weight per grain, oil concentration, and solar radiation intercepted during grain filling in black hull and striped hull sunflower hybrids. Crop Science Society of America, v. 48, n. 2, p. 688-699, 2008.

MALAVOLTA, E.; VITTI, G. C.; OLIVEIRA, S. A. Avaliação do estado nutricional das plantas: princípios e aplicações. Piracicaba: Potafos, 1997. 319 p.

MARCHESINI, M. J. et al. Desempenho de genótipos de girassol cultivados em segunda safra. Profiscientia, n. 11, p. 4657, 2018.

PIVETTA, L. G. et al. Avaliação de híbridos de girassol e relação entre parâmetros produtivos e qualitativos. Revista Ciência Agronômica, v. 43, n. 3, p. 561-568, 2012.

POLETINE, J. P. et al. Avaliações morfoagronômicas e teor óleo em genótipos de girassol nas condições do Arenito Caiuá. Journal of Agronomic Sciences, v. 2, n. 2, p. 105-117, 2013.

REETZ JUNIOR, H. F. Fertilizantes e seu uso eficiente. Tradução de Alfredo Scheid Lopes. São Paulo: Associação Nacional para Difusão de Adubos, 2017.

RIBEIRO, A. C.; GUIMARÃES, P. T. G.; ALVAREZ, V. H. (org.). Recomendações para o uso de corretivos e fertilizantes em Minas Gerais: $5^{\text {a }}$ aproximação. Viçosa, MG: Comissão de Fertilidade do Solo do Estado de Minas Gerais, 1999.

SOARES, L. U. et al. Crescimento e produtividade do girassol sob doses de nitrogênio e fósforo. Revista Brasileira de Agropecuária Sustentável, v. 6, n. 2, p. 19-25, 2016.

SOARES, L. U. et al. Fitomassa e produção do girassol cultivado sob diferentes níveis de reposição hídrica e adubação potássica. Revista Brasileira de Engenharia Agrícola e Ambiental, v. 19, n. 4, p. 336-342, 2015.

SOUZA, F. R. et al. Características agronômicas do cultivo de girassol consorciado com Brachiaria ruziziensis. Revista Ciência Agronômica, v. 46, n. 1, p. 110-116, 2015.

UCHÔA, S. C. P. et al. Adubação de potássio em cobertura nos componentes de produção de cultivares de girassol. Revista Ciência Agronômica, v. 42, n. 1, p. 8-15, 2011.

VIANA, T. V. A. et al. Diferentes doses de potássio, na forma de nitrato de potássio, aplicadas via fertirrigação no mamão formosa. Revista Ciência Agronômica, v. 39, n. 1, p. 34-38, 2008.

YANIV, Z. et al. Oil and fatty acid changes in sinapis and crambe seeds during germination and early development. Industrial Crops and Products, v. 9, n. 1, p. 1-8, 1998.

ZOBIOLE, L. H. S. et al. Marcha de absorção de macronutrientes na cultura do girassol. Revista Brasileira de Ciência do Solo, v. 34 , n. 2 , p. 425-433, 2010. 